\title{
MENENTUKAN PRODUKSI ENERGI (kWh) PADA PERENCANAAN PEMBANGKIT LISTRIK TENAGA MIKRO HIDRO (PLTMH) SUNGAI AEK SILANG di KABUPATEN HUMBANG HASUNDUTAN
}

\author{
Partahi H. Lumbangaol ${ }^{1}$, Salomo Simanjuntak ${ }^{2}$ \\ Fakultas Teknik Sipil Universitas HKBP Nommensen \\ Email: partahi.lumbangaol@uhn.ac.id ${ }^{1}$, salomo.simanjuntak@uhn.ac.id ${ }^{2}$
}

\begin{abstract}
This study concerned with designing a micro hydro power generation. The capacity of the plant is calculated on the basis of dependable flow, namely the amount of discharge that is equalled or exceeded during a certain period or with certain probability. Large designed flow have low probability of occurence. Small designed flow is more likely to occur but only produce little electrical power. Designed flow has big influence to production cost of each $\mathrm{kWh}$ of power generated. In this study, optimum designed flow is obtained through optimisation of parameter such as cost of producing $1 \mathrm{kWh}$ power from several value of dependable flow. This study conclude that an optimum economic value can be reached by dependable flow of $8,165 \mathrm{~m}^{3} / \mathrm{s}$ with $45 \%$ probability. The cost of producing the power is $\mathrm{Rp} 557.54$ per $\mathrm{kWh}$. The plant generates approximately 64.530.792,94 kWh electrical power in one year.
\end{abstract}

Keywords: Dependable Flow, Micro Hydro Power Generation

\section{PENDAHULUAN}

\subsection{Latar Belakang}

Propinsi Sumatera Utara memiliki potensi energi listrik bersumber tenaga air yang sangat besar. Hal ini dipaparkan dalam buku Rencana Induk Pengembangan Energi Baru Terbarukan (RIPEBAT) 2010-2025. Meskipun demikian potensi ini belum semua dimanfaatkan secara optimal. Propinsi ini masih sering alami pemadaman listrik. Pemadaman sering terjadi pada saat adanya gangguan maupun perawatan berkala di beberapa pembangkit besar yang menggunakan bahan bakar fossil (Abdul Rahman, 2017). Mengingat pertumbuhan ekonomi dan pertumbuhan kebutuhan daya listrik di wilayah ini, boleh dikatakan Propinsi Sumatera Utara akan segera mengalami krisis listrik jika tidak ada tambahan pasokan listrik dalam waktu dekat.

Dengan ikut sertanya Indonesia meratifikasi kesepakatan pengurangan emisi karbon pada COP 21 tentang Perubahan Iklim tahun 2015 yang lalu di Paris, maka penambahan pasokan daya listrik yang sesuai haruslah memiliki emisi karbon yang rendah. Dengan kata lain pemanfaatan potensi pembangkit menggunakan energi air menjadi solusi yang sesuai. Hal ini sesuai dengan pidato Presiden Jokowi pada COP 21 yang antara lain menyebutkan bahwa penurunan emisi di bidang energi akan 
mengambil langkah peningkatan penggunaan sumber energi terbarukan hingga $23 \%$ dari konsumsi energi nasional tahun 2025.

Sehubungan dengan itu, pemerintah telah mewajibkan PLN untuk membeli produksi listrik yang dihasilkan dari pembangkit dengan energi terbarukan seperti pembangkit listrik tenaga air. Sesuai dengan ketetapan pemerintah (PERMEN ESDM no 19 tahun 2015) harga jual listrik dari Pembangkit Listrik Tenaga Mikro Hydro (PLTMH) saat ini berkisar antara Rp 1.560 hingga Rp 2.080 per kWh. Hal ini menarik banyak investor terjun mengembangkan usaha pembangkit listrik di wilayah Propinsi Sumatera Utara.

Salah satu daerah yang potensil yang diangkat menjadi obyek penelitian dalam studi ini adalah kawasan kecamatan Bakti Raja di Kabupaten Humbang Hasundutan, dengan beberapa sungai kecil yang bermuara ke Danau Toba antara lain sungai Aek Silang dan sungai Aek Simangira. Dalam studi ini penulis memilih Aek Silang yang memiliki debit lebih besar yaitu sekitar $10 \mathrm{~m} 3 /$ detik.

Penelitian ini bertujuan menghitung besarnya produksi kWh yang dapat dijual kepada PLN dalam setahun. Produksi kWh akan dihitung berdasarkan debit andalan 90\% dan debit andalan 45\%. Perhitungan produksi $\mathrm{kWh}$ berdasarkan beberapa debit andalan di sini bertujuan memberi pemahaman tentang potensi listrik yang dapat dihasilkan maupun yang dapat hilang akibat pemilihan debit andalan tertentu.

Permasalahan dalam perencanaan adalah : debit andalan yang besar memiliki peluang yang kecil sehingga dapat berakibat terganggunya operasi turbin pada saat debit yang mengalir tidak tercapai karena jauh lebih kecil. Di sisi lain debit andalan yang kecil dapat diandalkan sepanjang tahun, namun hanya dapat menghasilkan produksi kWh yang rendah. Sementara PLN sebagai pembeli listrik hanya membayar sejumlah kWh yang diproduksi PLTM. Oleh karenanya pengembang perlu memilih debit yang optimal untuk mendapatkan keuntungan yang maksimal.

\subsection{STUDI LITERATUR}

Pembangkit Listrik Tenaga Mikro Hydro memanfaatkan energi air yang jatuh dari ketinggian tertentu untuk memutar turbin pembangkit listrik. Besarnya energi 
listrik yang dihasilkan sebanding dengan tinggi jatuh dan besarnya debit aliran. Secara matematis hubungan ini dapat dituliskan sebagai berikut :

$$
P=\eta t \cdot \eta g \cdot g \cdot Q d \cdot H n
$$

dimana :

$$
\begin{aligned}
& \mathrm{P} \quad=\text { Kapasitas, }(\mathrm{kW}) \\
& \eta \mathrm{t} \quad \text { Effisiensi Turbine } \\
& \eta \mathrm{g}=\text { Effisiensi Generator } \\
& \mathrm{g} \quad=\text { Gravitasi, }\left(=9.8 \mathrm{~m}^{2} / \mathrm{dt}\right) \\
& \mathrm{Qd}=\text { Debit perencanaan, }\left(\mathrm{m}^{3} / \mathrm{det}\right) \\
& \mathrm{Hn}=\text { Tinggi efektif jatuhnya air }=\mathrm{Hg}-\square \mathrm{H},(\mathrm{m})
\end{aligned}
$$

Mengingat aliran air sungai yang selalu dinamis dan berfluktuasi, maka besarnya Qd harus ditentukan dengan teliti sehingga kapasitas (P) dapat diperhitungkan dengan cermat. Pada saat debit yang mengalir jauh lebih besar dari debit rencana (Qd) turbin tetap dapat beroperasi dengan baik karena kelebihan air akan terbuang melalui saluran pembuang. Pada saat debit yang mengalir jauh lebih kecil dari debit rencana (Qd) maka turbin akan berhenti bekerja.

Ketika sistem pembangkit berada ditempat yang jauh dari sumber listrik lain, maka sitem tersebut harus dirancang mampu bekerja sepanjang tahun. Untuk itu debit andalan 95\% perlu dipilih. Di sisi lain, ketika PLTM yang dirancang berada dalam daerah dimana terdapat banyak sumber listrik lain yang bersama-sama memasok listrik, maka debit andalan dengan peluang lebih kecil lebih tepat dipilih. Hal ini dikarenakan produksi kWh yang dihasilkan lebih banyak. Harga jual listrik ke PLN menjadi lebih besar. Investasi lebih cepat kembali.

Meskipun demikian, pemilihan debit andalan dengan peluang yang kecil bukan tanpa kelemahan. Debit andalan dengan peluang kecil sering mengakibatkan unit PLTM yang kita rencanakan tidak dapat beroperasi karena debit yang mengalir jauh lebih kecil dari debit rencana. Namun hal ini diharapkan tidak akan mengganggu pasokan ke daerah tersebut apabila ditempat itu tersedia sumber listrik lain. 
Menentukan besarnya debit andalan dilakukan dengan melakukan analisa hidrologi berdasarkan data aliran air sungai pada waktu-waktu sebelumnya. Apabila data aliran tidak tersedia dengan cukup, maka dilakukan dengan memperhitungkan besarnya debit berdasarkan curah hujan yang ada pada stasiun-stasiun hujan terdekat. Data curah hujan selanjutnya di kalikan dengan luas daerah aliran sungai dan melalui pemodelan dikonversikan menjadi debit aliran sungai. Pemodelan yang digunakan akan memperhitungkan hilangnya air selama perjalanan dari daerah aliran sungai menuju badan sungai.

Berdasarkan langkah diatas, selanjutnya dilakukan analisa simulasi debit aliran rendah (Low Flow). Ada beberapa model yang tersedia namun studi ini hanya akan menggunakan metode Tank Model. Metode ini dapat digambarkan sebagai berikut :
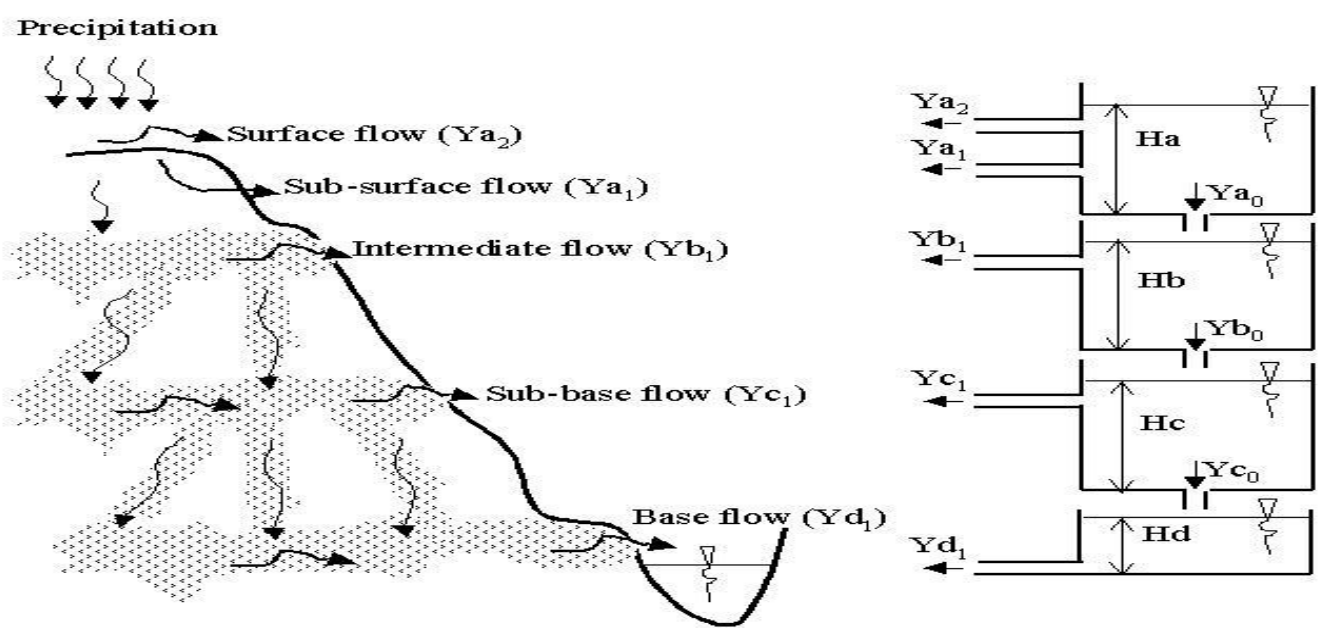

\section{Gambar 1. Skema Tank Model}

Gambar 1. menunjukkan Standard Tank Model dan pergerakkan air hipotesis dalam suatu DAS. Pemilihan model Tank ini adalah untuk meniru (simulate) daerah pengaliran sungai dengan menggantikannya oleh sejumlah tampungan yang digambarkan sebagai deret tangki. Model tersebut dikembangkan oleh DR. M. Sugawara. Model Tank yang digunakan dalam studi ini tersusun atas 4 (empat) reservoir vertical, dimana bagian atas merepresentasikan Surface Reservoir (Tank 1), dibawahnya Intermediate Reservoir (Tank 2), kemudian Sub-base Reservoir (Tank 3) dan paling bawah Base Reservoir (Tank 4). Dalam konsep ini aliran yang melewati lubang-lubang yang berada di dinding kanan tangki-tangki yang bersangkutan 
menghasilkan limpasan, sedangkan aliran yang melewati dasar tangki merupakan infiltrasi.

Curah hujan yang jatuh pada suatu waktu $\mathrm{R}(\mathrm{t})$ akan mengisi tangki paling atas (Tank 1) air yang tertampung di Tank 1 akan mengalir melewati lubang-lubang di dinding kanan dan merembes lewat lubang di dasar tanki dan masuk mengisi Tank 2 dalam tahap kedua. Air yang tertampung dalam tank 2 mengalir melewati lubanglubang di dinding kanan dan merembes lewat lubang di dasar tanki dan masuk mengisi Tank 3 dalam tahap ketiga. Proses ini berulang sampai dengan Tanki terakhir.

Secara umum persamaan keseimbangan air pada Tank Model sebagai berikut:

$$
\mathrm{dH} / \mathrm{dt}=\mathrm{P}(\mathrm{t})-\mathrm{ET}(\mathrm{t})-\mathrm{Y}(\mathrm{t})
$$

dimana:

$$
\begin{aligned}
& \mathrm{H}=\text { tinggi air }(\mathrm{mm}) \\
& \mathrm{P}=\text { hujan (mm/hari) } \\
& \mathrm{ET}=\text { Evapotranspirasi (mm/hari) } \\
& \mathrm{Y}=\text { aliran total (mm/day) } \\
& \mathrm{T}=\text { Waktu (hari) }
\end{aligned}
$$

Aliran total merupakan pejumlahan dari komponen aliran yang dapat ditulis sebagai berikut:

$$
\mathrm{q}(\mathrm{t})=\mathrm{q} 1(\mathrm{t})+\mathrm{q} 2(\mathrm{t})+\mathrm{q} 3(\mathrm{t})+\mathrm{q} 4(\mathrm{t})
$$

Besaran debit yang dihasilkan dari model ini dapat digunakan untuk membentuk Flow Duration Curve (FDC) yang merupakan grafik debit dan peluang terjadinya debit aliran tersebut. FDC untuk setiap bagian aliran sungai berbeda. Oleh karena nya FDC dibentuk harus pada segmen dimana akan dibangun intake untuk PLTM. Contoh FDC dapat dilihat pada Gambar 2 berikut : 


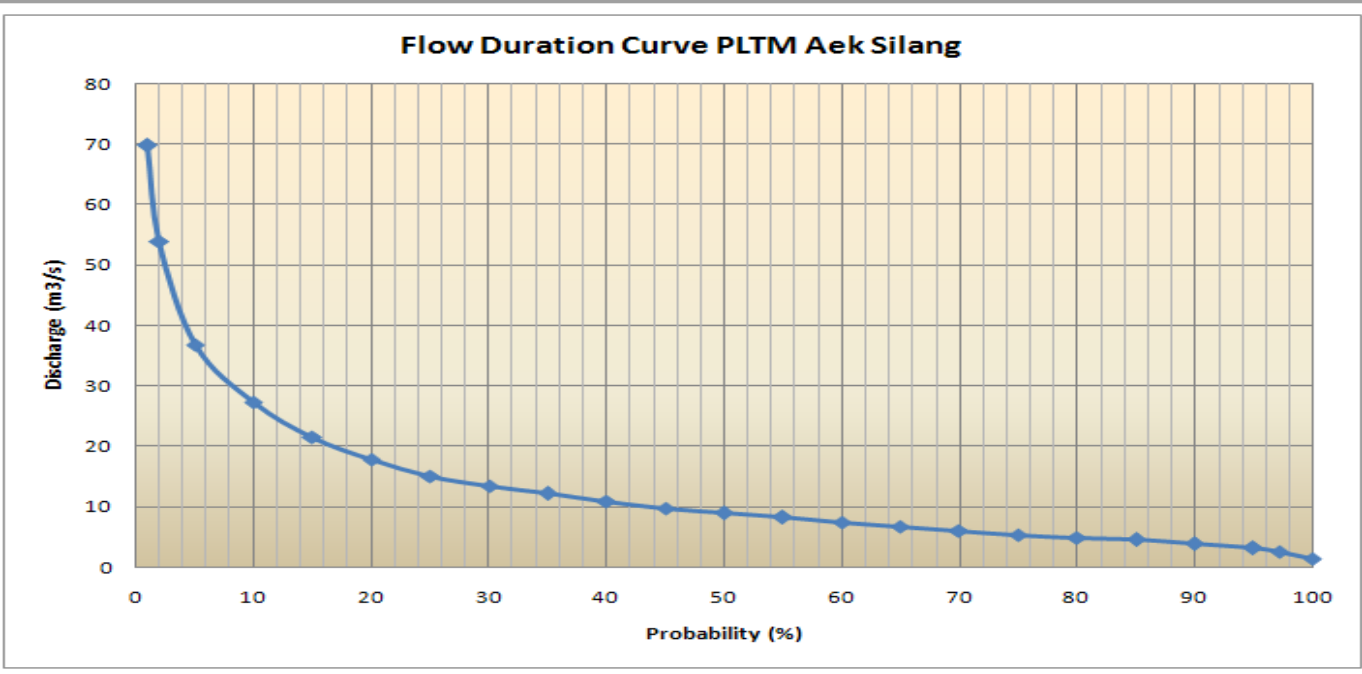

\section{Gambar 2. Flow Duration Curve}

Flow duration curve menunjukkan persentase waktu dari debit yang sama atau lebih selama periode pencatatan data. Kurva ini menunjukkan karakteristik dari aliran atau debit. Flow duration curve ini dapat dibentuk dari data debit harian, rata-rata 10 harian, rata-rata 15 harian dan rata-rata bulanan.

Pada Gambar 2 diatas dapat dilihat probabilitas setiap debit yang diharapkan terjadi pada segmen sungai yang diamati. Contoh debit sekitar $10 \mathrm{~m} 3 /$ det. memiliki probabilitas $45 \%$. Debit sekitar $5 \mathrm{~m} 3 /$ det. memiliki probabilitas $80 \%$. Yang dimaksud dengan probabilitas $45 \%$ pada FDC ini adalah debit tersebut akan terlampaui atau setidaknya tercapai selama 45\% x 365 hari atau sekitar 164 hari.

Selanjutnya debit andalan yang dipilih dengan probabilitas tertentu akan digunakan untuk menetapkan kapasitas PLTM seperti dalam persamaan (1) diatas.

Energi yang dihasilkan dari PLTM ataupun $\mathrm{kWh}$ yang dijual kepada PLN dihitung dengan rumus :

$$
\mathrm{E}=\xi \cdot \mathrm{P} .8760
$$

dimana :

$\mathrm{P} \quad=$ Kapasitas, $(\mathrm{KW})$

$\xi=$ Plant factor

Received May 14 ${ }^{\text {th }}$, 2020; Revised June 20t ${ }^{h}$ 2020; Accepted 20th, 2020 
Energi dalam persamaan ini adalah ukuran berapa lama daya tertentu $(\mathrm{kW})$ digunakan maupun dihasilkan. PLN sebagai pembeli mencatat berapa lama pasokan daya memasuki jarinngan milik mereka dengan satuan $\mathrm{kWh}$.

\subsection{RUMUSAN MASALAH :}

Perencanaan kapasitas pembangkit dengan menggunakan debit andalan yang memiliki probabilitas besar (debit kecil) berakibat hilangnya potensi aliran air yang mengalir pada sebuah sungai. Di lain sisi, perencanaan pembangkit dengan menggunakan debit andalan yang memiliki probabilitas kecil (debit besar) dapat mengakibatkan seringnya sistem pembangkit berhenti beroperasi. Hal ini dikarenakan turbin yang dipasang tidak dapat bekerja pada debit yang jauh dibawah debit kerjanya. Akibatnya besaran debit andalan yang dipilih akan mempengaruhi biaya produksi setiap $\mathrm{kWh}$ listrik yang dihasilkan.

\subsection{TUJUAN PENELITIAN :}

Penelitian ini bertujuan menentukan berapa debit andalan yang dapat menghasilkan produksi daya (kWh) dengan biaya optimum serta berapa besar potensi $\mathrm{kWh}$ yang dihasilkan pada debit optimum tersebut.

\section{METODOLOGI DAN DATA PENELITIAN}

Metodologi yang digunakan dalam penelitian ini adalah survey literature, analisa hidrologi dan pengamatan lapangan, Obyek pengamatan adalah sungai Aek Silang yang lokasinya berada di Kecamatan Bakti Raja Kabupaten Humbang Hasundutan Propinsi Sumatera Utara. Studi sebelumnya oleh peneliti menunjukkan debit sungai sesaat sekitar $10 \mathrm{~m} 3 /$ det. Sungai Aek Silang berada pada dataran tinggi sekitar 1.300 mdpl dan bermuara di Danau Toba pada ketinggian sekitar 900 m dpl.

\section{METODE PENELITIAN}

\section{ANALISA HIDROLOGI}

Analisa Hidrologi dilakukan untuk mendapatkan besarnya debit andalan yang akan digunakan oleh pembangkit listrik dan penentuan debit banjir rancangan. Untuk maksud tersebut akan diperlukan pengumpulan semua data Hidrologi-Klimatologi yang ada untuk daerah lokasi proyek seperti data hujan, data Iklim, penguapan, data debit 
sungai dan sebagainya untuk periode waktu yang panjang. Analisa Hidrologi akan mencakup :

- Pembuatan kurva debit (Flow Duration Curve - FDC) sebagai dasar penentuan Debit Andalan Pembangkit (Dependable Flow)

- Pengukuran Debit Sesaat dengan peralatan Current Meter pada lokasi rencana Bendung dan Saluran Pembuang (Tail Race)

- Analisa Aliran Rendah (Low Flow) untuk mendapatkan karakteristik Debit Jangka Panjang serta menentukan ketersediaan air untuk Pembangkit PLTM

\subsection{Data Hidrologi}

\subsubsection{Data DAS PLTM Aek Silang-2}

Pembangkit Listrik Tenaga Air Mikro Hidro pada Sungai Aek Silang merupakan seasonal run off river yang membangkitkan energi listrik dengan memanfaatkan sumber daya air DAS PLTM Aek Silang-2. Pola aliran sungai di Sungai Aek Silang mengikuti pola dendritik, artinya pola aliran sungai yang bentuknya seperti percabangan pohon, tidak teratur dengan arah dan sudut yang beragam di mana sungai induk memperoleh aliran dari anak sungainya.

DAS PLTM Aek Silang-2 memiliki luas $276.90 \mathrm{~km}^{2}$ dengan panjang sungai 35 km. Pengoperasian PLTM hanya mengandalkan ketersediaan air pada Sungai Aek Silang.

\section{Data Curah Hujan}

\section{A. Ketersediaan Data Curah Hujan}

Kualitas sebuah analisa hidrologi sangat bergantung kepada ketersediaan data. Dalam hal ini peneliti melakukan pengumpulan data hidrologi dari stasiun hidrologi yang lokasinya terdapat pada wilayah studi. Stasiun penakar hujan terdekat yang berada pada wilayah studi adalah Stasiun Hujan Dolok Sanggul, Stasiun Hujan Harian Boho dan Stasiun Hujan Parlilitan.

Data yang tersedia pada ketiga stasiun hujan ini sepanjang 17 tahun, yaitu mulai tahun 1993 s/d 2009. Berikut ini tabel kesediaan data di tiap stasiun yang masuk dalam DAS PLTM Aek Silang-2. 
Tabel 1. Ketersediaan Data Hujan di Stasiun Hujan DAS Aek Silang-2

\begin{tabular}{|c|c|c|c|c|}
\hline \multirow[b]{2}{*}{ No } & \multirow[b]{2}{*}{ Tahun } & \multicolumn{3}{|c|}{ Stasiun Hujan } \\
\hline & & Parlilitan & $\begin{array}{c}\text { Dolok } \\
\text { Sanggul }\end{array}$ & Harian Boho \\
\hline 1 & 1993 & $\checkmark$ & $\checkmark$ & $\checkmark$ \\
\hline 2 & 1994 & $\checkmark$ & $\checkmark$ & $\checkmark$ \\
\hline 3 & 1995 & $\checkmark$ & $\checkmark$ & $\checkmark$ \\
\hline 4 & 1996 & $\checkmark$ & $\checkmark$ & $\checkmark$ \\
\hline 5 & 1997 & $\checkmark$ & $\sqrt{ }$ & $\checkmark$ \\
\hline 6 & 1998 & $\bar{\checkmark}$ & $\sqrt{ }$ & $\sqrt{ }$ \\
\hline 7 & 1999 & $\checkmark$ & $\checkmark$ & $\checkmark$ \\
\hline 8 & 2000 & $\checkmark$ & $\checkmark$ & $\checkmark$ \\
\hline 9 & 2001 & $\checkmark$ & $\checkmark$ & $\checkmark$ \\
\hline 10 & 2002 & $\checkmark$ & $\sqrt{ }$ & $\checkmark$ \\
\hline 11 & 2003 & $\checkmark$ & $\sqrt{ }$ & $\checkmark$ \\
\hline 12 & 2004 & $\checkmark$ & $\checkmark$ & $\checkmark$ \\
\hline 13 & 2005 & $\checkmark$ & $\checkmark$ & $\checkmark$ \\
\hline 14 & 2006 & $\checkmark$ & $\checkmark$ & $\checkmark$ \\
\hline 15 & 2007 & $\checkmark$ & $\checkmark$ & $\checkmark$ \\
\hline 16 & 2008 & $\checkmark$ & $\checkmark$ & $\checkmark$ \\
\hline 17 & 2009 & $\checkmark$ & $\checkmark$ & $\checkmark$ \\
\hline
\end{tabular}

Berikut adalah grafik kurva masa ganda curah hujan tahunan Stasiun Hujan Parlilitan, Stasiun Hujan Dolok Sanggul dan Stasiun Hujan harian Boho untuk tahun pengamatan $1993-2009$ : 


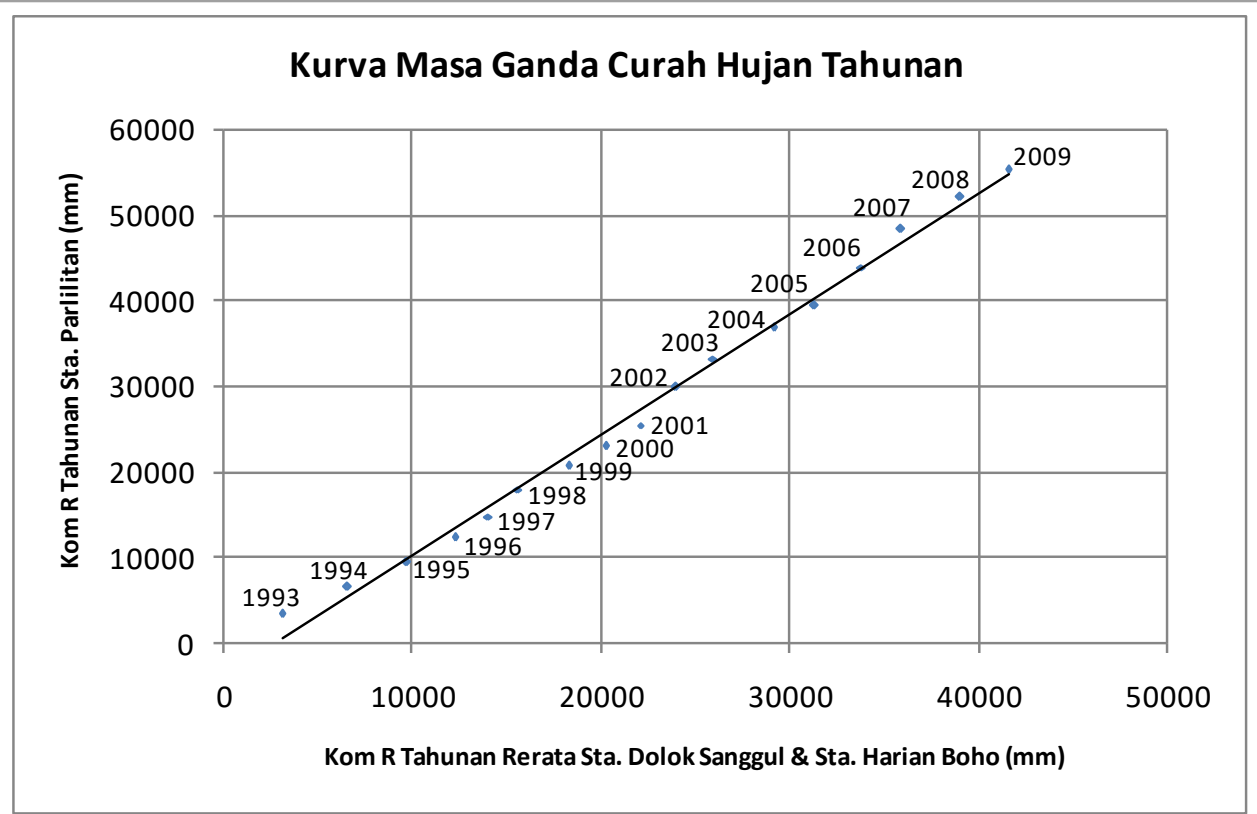

Gambar 4. Kurva Masa Ganda Curah Hujan Tahunan Sta. Parlilitan Terhadap Sta. Dolok Sanggul dan Sta. Harian Boho

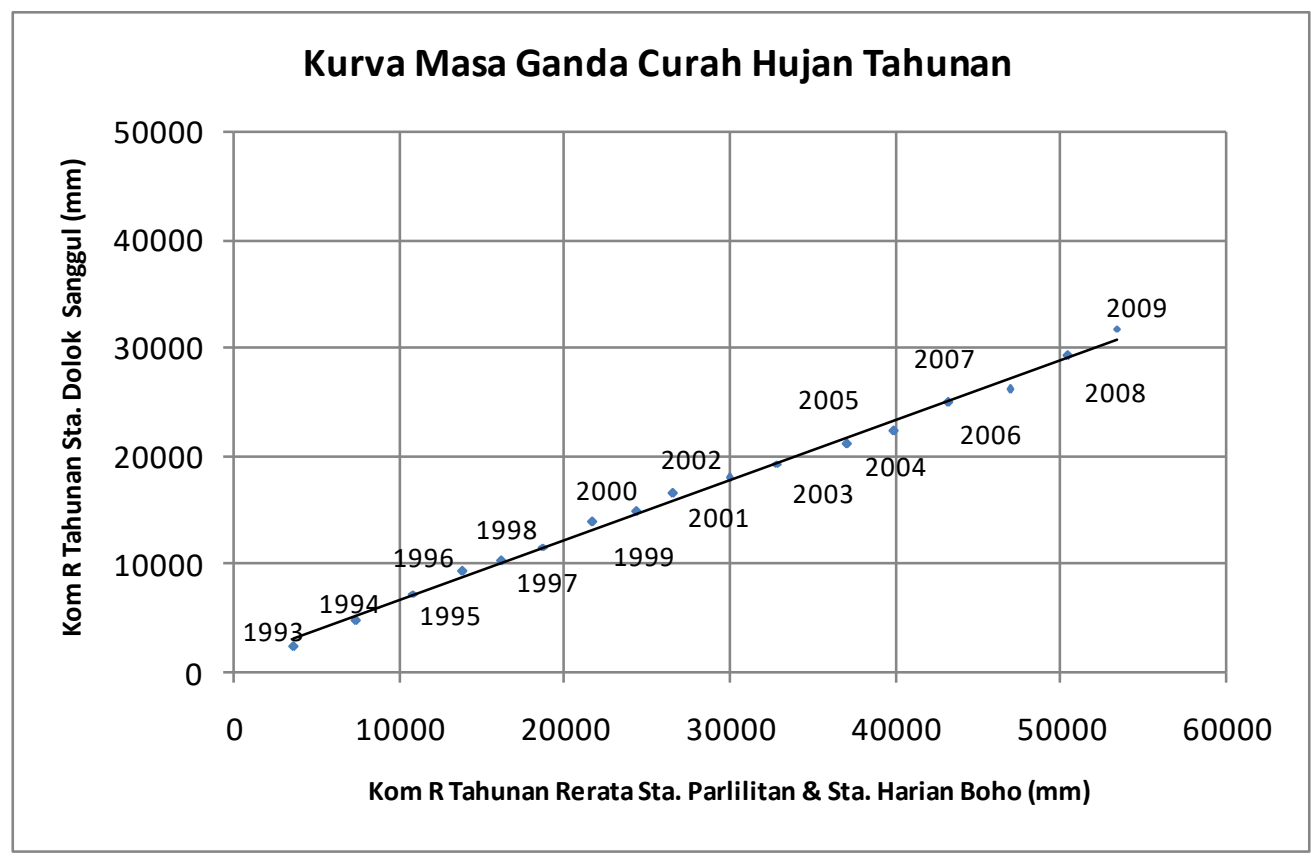

Gambar 5. Kurva Masa Ganda Curah Hujan Tahunan Sta. Dolok Sanggul Terhadap Sta. Parlilitan dan Sta. Harian Boho 


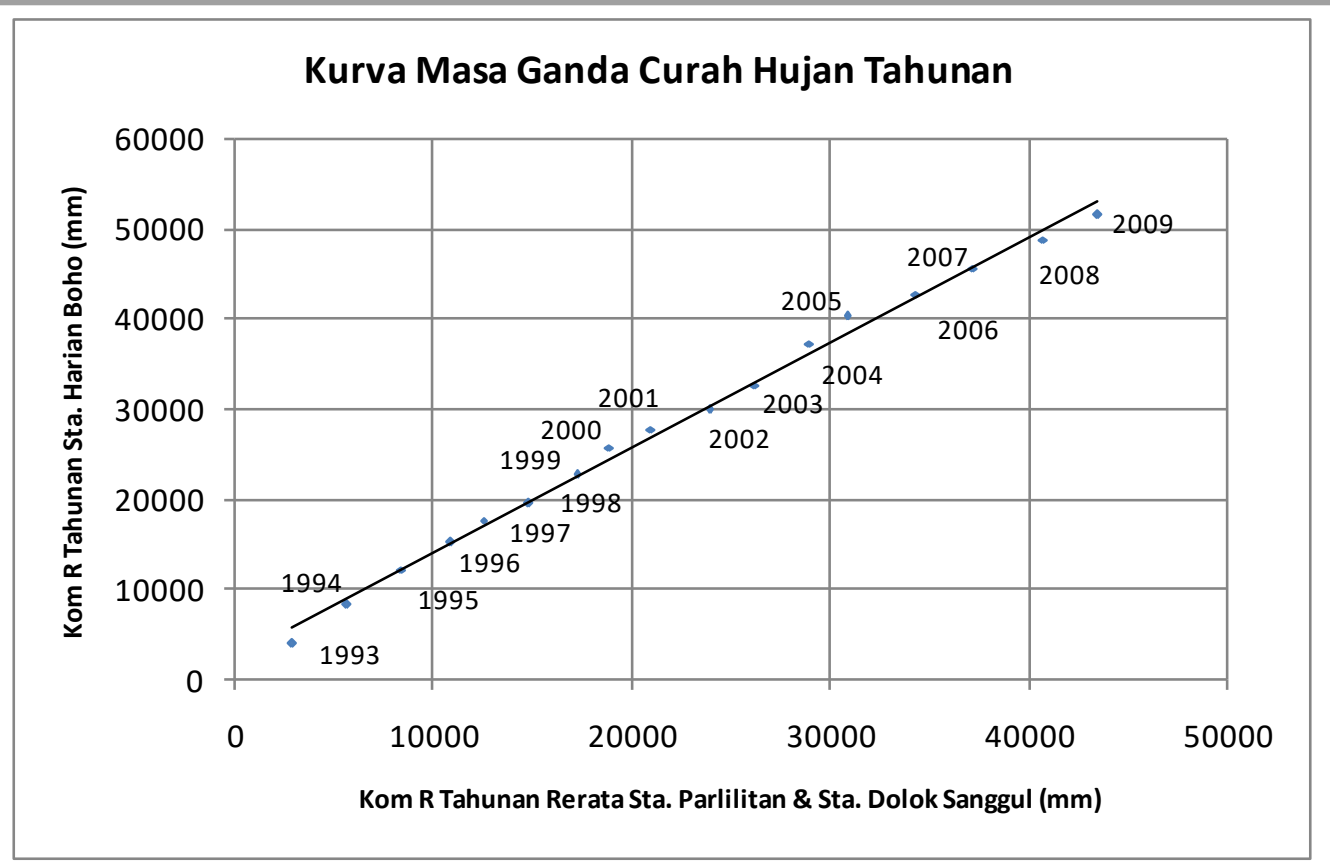

Gambar 6. Kurva Masa Ganda Curah Hujan Tahunan Sta. Harian Boho Terhadap Sta. Parlilitan dan Sta. Dolok Sanggul

Berdasarkan kurva masa ganda curah hujan tahunan diatas diperoleh kesamaan pola atau trend hasil pencatatan data hujan tahun 1993 - 2009 antara Stasiun Hujan Parlilitan, Stasiun Hujan Dolok Sanggul, dan Stasiun Hujan Harian Boho.

Tabel 2. Curah Hujan Tahunan dan Curah Hujan Maksimum Tahunan DAS PLTM Aek Silang-2 


\begin{tabular}{|c|c|c|c|c|c|c|c|}
\hline \multirow{2}{*}{ No } & \multirow{2}{*}{ Tahun } & \multicolumn{3}{|c|}{ Curah Hujan Tahunan (mm) } & \multicolumn{3}{c|}{ Curah Hujan Maksimum (mm) } \\
\cline { 3 - 8 } & & Dolok Sanggul & Harian Boho & Parlilitan & Dolok Sanggul & Harian Boho & Parlilitan \\
\hline 1 & 1993 & 2278 & 3840 & 3370 & 83.80 & 42.52 & 1.54 \\
2 & 1994 & 2509 & 4407 & 3114 & 49.17 & 75.29 & 4.75 \\
3 & 1995 & 2428 & 3867.3 & 2982 & 59.43 & 73.26 & 1.62 \\
4 & 1996 & 2054 & 3113 & 2909 & 26.93 & 31.18 & 19.27 \\
5 & 1997 & 1017 & 2414 & 2376 & 15.93 & 21.52 & 17.40 \\
6 & 1998 & 1266 & 1880 & 3195 & 28.92 & 24.10 & 1.48 \\
7 & 1999 & 2258 & 3217 & 2699 & 138.15 & 138.26 & 21.18 \\
8 & 2000 & 937.7 & 2975 & 2389 & 44.04 & 29.28 & 4.46 \\
9 & 2001 & 1704.1 & 1997 & 2421 & 63.02 & 45.58 & 5.97 \\
10 & 2002 & 1483.2 & 2258 & 4461 & 24.13 & 24.44 & 4.97 \\
11 & 2003 & 1319 & 2664 & 3252 & 28.25 & 32.64 & 3.47 \\
12 & 2004 & 1780.3 & 4661 & 3706.5 & 34.07 & 38.85 & 11.68 \\
13 & 2005 & 1219.6 & 3019 & 2606 & 21.76 & 39.89 & 18.04 \\
14 & 2006 & 2606 & 2397 & 4367 & 53.94 & 25.52 & 8.01 \\
15 & 2007 & 1295 & 2871 & 4453 & 33.38 & 20.32 & 12.05 \\
16 & 2008 & 3115.8 & 3176 & 3895 & 86.11 & 34.22 & 31.05 \\
17 & 2009 & 2472.6 & 2727 & 3061 & 41.55 & 48.55 & 41.77 \\
\hline
\end{tabular}

\section{A. Data Curah Hujan Tahunan}

Data curah hujan tahunan DAS PLTM Aek Silang-2 diperoleh dari tiga stasiun hujan terdekat, yaitu Stasiun Hujan Parlilitan, Stasiun Hujan Dolok Sanggul, dan Stasiun Hujan Harian Boho. Adapun besarnya curah hujan tahunan dan curah hujan maksimum tahunan dari tiga Stasiun Hujan tersebut daapt dilihat pada tabel diatas.

Berdasarkan tabel curah hujan diatas diketahui curah hujan tahunan pada Stasiun Hujan Dolok Sanggul 937.7 - 3115.8 mm/tahun, pada Stasiun Hujan Harian Boho 1880 - 4661 mm/tahun, sedangkan pada Stasiun Hujan Parlilitan 2376 - 4461 mm/tahun. Untuk curah hujan maksimum tahunan pada Stasiun Hujan Dolok Sanggul curah hujan maksimum pada tahun 1999 sebesar 138.15 mm, pada Stasiun Hujan Harian Boho curah hujan maksimum pada tahun 1999 yaitu sebesar 138.26, sedangkan pada Stasiun Hujan Parlilitan curah hujan maksimum terjadi pada tahun 2009 sebesar $41.77 \mathrm{~mm}$.

\section{B. Curah Hujan Rerata Daerah}

Curah hujan rerata daerah untuk DAS PLTM Aek Silang-2 dihitung menggunakan data curah hujan harian dari tiga stasiun hujan terdekat, yaitu Stasiun Hujan Dolok Sanggul, dan Stasiun Hujan Harian Boho. Metode yang digunakan dalam 
perhitungan curah hujan rerata daerah dalam DAS Aek Silang-2 dihitung dengan menggunakan metode Poligon Thiessen. Cara ini memperhitungkan luas daerah yang diwakili stasiun yang berpengaruh sebagai faktor koreksi dalam menghitung hujan ratarata. Adapun perhitungannya disajikan dalam bentuk tabel sebagai berikut:

Tabel 3. Curah Hujan Rerata Tahunan DAS PLTM Aek Silang-2

\begin{tabular}{|c|c|c|c|c|c|}
\hline \multirow[b]{2}{*}{ No } & \multirow[b]{2}{*}{ Tahun } & \multicolumn{3}{|c|}{ Curah Hujan Rerata Tahunan } & \multirow{2}{*}{$\begin{array}{l}\text { Curah Hujan } \\
\text { Max. Tahunan } \\
\text { R (mm) }\end{array}$} \\
\hline & & $\begin{array}{c}\text { Dolok Sanggul } \\
\text { R (mm) }\end{array}$ & $\begin{array}{c}\text { Harian Boho } \\
\text { R (mm) }\end{array}$ & $\begin{array}{c}\text { Parlilitan } \\
\mathbf{R}(\mathrm{mm})\end{array}$ & \\
\hline 1 & 1993 & 83.80 & 42.52 & 1.54 & 83.80 \\
\hline 2 & 1994 & 49.17 & 75.29 & 4.75 & 75.29 \\
\hline 3 & 1995 & 59.43 & 73.26 & 1.62 & 73.26 \\
\hline 4 & 1996 & 26.93 & 31.18 & 19.27 & 31.18 \\
\hline 5 & 1997 & 15.93 & 21.52 & 17.40 & 21.52 \\
\hline 6 & 1998 & 28.92 & 24.10 & 1.48 & 28.92 \\
\hline 7 & 1999 & 138.15 & 138.26 & 21.18 & 138.26 \\
\hline 8 & 2000 & 44.04 & 29.28 & 4.46 & 44.04 \\
\hline 9 & 2001 & 63.02 & 45.58 & 5.97 & 63.02 \\
\hline 10 & 2002 & 24.13 & 24.44 & 4.97 & 24.44 \\
\hline 11 & 2003 & 28.25 & 32.64 & 3.47 & 32.64 \\
\hline 12 & 2004 & 34.07 & 38.85 & 11.68 & 38.85 \\
\hline 13 & 2005 & 21.76 & 39.89 & 18.04 & 39.89 \\
\hline 14 & 2006 & 53.94 & 25.52 & 8.01 & 53.94 \\
\hline 15 & 2007 & 33.38 & 20.32 & 12.05 & 33.38 \\
\hline 16 & 2008 & 86.11 & 34.22 & 31.05 & 86.11 \\
\hline 17 & 2009 & 41.55 & 48.55 & 41.77 & 48.55 \\
\hline
\end{tabular}

Berdasarkan tabel curah hujan diatas diketahui curah hujan rerata maksimum tahunan sebesar $138.26 \mathrm{~mm}$ terjadi pada tahun 1999. Curah hujan rerata tahunan DAS PLTM Aek Silang-2 dihitung dengan metode Poligon Thiessen dengan menggunakan tiga Stasiun Hujan.

\section{Data Debit}

Pada sungai Aek Silang ini tidak terdapat pencatatan debit aliran sungai yang lengkap, sehingga debit andalan dihitung dengan menggunakan metode simulasi hujan menjadi aliran (Rainfall - runoff model). Untuk memperkirakan besarnya debit pada lokasi rencana PLTM dilakukan melalui pemodelan simulasi debit dengan menggunakan metode Tank Model. 


\subsection{Analisa Hidrologi}

\subsubsection{Curah Hujan Rancangan}

Curah hujan rencana adalah hujan terbesar tahunan dengan peluang tertentu yang mungkin terjadi di suatu daerah, atau hujan dengan suatu kemungkinan periode ulang tertentu.

Analisa curah hujan rancangan meliputi :

a. Uji konsistensi data menggunakan uji lengkung massa ganda yaitu membandingkan akumulasi data curah hujan tahunan stasiun yang bersangkutan dengan akumulasi data curah hujan rata-rata sekelompok stasiun dalam periode yang sama.

b. Menentukan curah hujan harian maksimum setiap tahun pencatatan.

c. Analisa hujan rancangan menggunakan metode Distribusi Normal, Log Pearson Type III, dan E.j. Gumble, kemudian hasilnya dipilih yang paling realistis dan dilakukan uji kesuaian distribusi dengan metode Chi Square dan Smirnov Kolmogorof.

Dari hasil perhitungan curah hujan rancangan dengan metode Distribusi Normal, Log Pearson Type III, dan E.J. Gumble, dipilih curah hujan rancangan menggunakan metode Log Pearson Type III karena setelah dilakukan hasil pengujian, parameter dasar statistiknya lebih memenuhi batas atau syarat pengujian penggunaan analisa frekuensi dan hasilnya lebih realistis. Hasil perhitungan curah hujan rancangan metode Log Pearson Type III dapat dilihat pada Tabel 4.

\section{Tabel 4. Curah Hujan Rancangan Metode Log Pearson Tipe III}

\begin{tabular}{|c|c|c|}
\hline No. & $\begin{array}{c}\text { Periode Ulang (Tr) } \\
\text { Tahun }\end{array}$ & $\begin{array}{c}\text { C.H. Rancangan } \\
\text { (mm) }\end{array}$ \\
\hline 1 & 1.01 & 16.810 \\
2 & 2 & 45.998 \\
3 & 5 & 72.028 \\
4 & 10 & 92.841 \\
5 & 25 & 123.439 \\
6 & 50 & 149.643 \\
7 & 100 & 178.904 \\
8 & 200 & 211.703 \\
9 & 1000 & 242.222 \\
\hline
\end{tabular}




\section{Debit Andalan}

Untuk mengetahui ketersediaan air di daerah pengaliran sungai (DAS) lokasi rencana PLTM Aek Silang-2 khususnya besarnya debit aliran rendah (low flow) perlu dilakukan analisa simulasi aliran rendah. Analisa debit andalan pada studi kelayakan PLTM Aek Silang-2 dilakukan dengan menggunakan metode Tank Model kemudian dibandingkan dengan hasil running dari software HEC-HMS

\subsubsection{Debit Andalan dengan metode Tank Model}

Berdasarkan simulasi Tank Model besarnya debit andalan pada daerah pengaliran sungai (DAS) PLTM Aek Silang-2 dengan berbagai macam keandalan disajikan dalam bentuk Tabel 5 berikut:

Tabel 5 Debit Andalan DAS PLTM Aek Silang-2

\begin{tabular}{|c|c|c|}
\hline $\begin{array}{l}\text { Probability } \\
(\%)\end{array}$ & $\begin{array}{l}\text { Frequency } \\
\text { (days) }\end{array}$ & $\begin{array}{l}\text { Discharge } \\
\left(\mathrm{m}^{3} / \text { detik }\right)\end{array}$ \\
\hline 1.00 & 3.65 & 69.798 \\
\hline 2.00 & 7.30 & 53.983 \\
\hline 5.00 & 18.25 & 36.821 \\
\hline 10.00 & 36.50 & 27.270 \\
\hline 15.00 & 54.75 & 21.498 \\
\hline 20.00 & 73.00 & 17.775 \\
\hline 25.00 & 91.25 & 15.111 \\
\hline 30.00 & 109.50 & 13.423 \\
\hline 35.00 & 127.75 & 12.166 \\
\hline 40.00 & 146.00 & 10.879 \\
\hline 45.00 & 164.25 & 9.780 \\
\hline 50.00 & 182.50 & 8.959 \\
\hline 55.00 & 200.75 & 8.221 \\
\hline 60.00 & 219.00 & 7.499 \\
\hline 65.00 & 237.25 & 6.736 \\
\hline 70.00 & 255.50 & 6.047 \\
\hline 75.00 & 273.75 & 5.312 \\
\hline
\end{tabular}




\begin{tabular}{|l|l|l|}
80.00 & 292.00 & 4.920 \\
\hline 85.00 & 310.25 & 4.548 \\
\hline 90.00 & 328.50 & 3.830 \\
\hline 95.00 & 346.75 & 3.145 \\
\hline 97.26 & 355.00 & 2.518 \\
\hline 100.00 & 365.00 & 1.350 \\
\hline
\end{tabular}

Kurva durasi debit (Flow duration curve) menunjukkan prosentase waktu dari debit yang sama atau lebih selama periode pencatatan data. Kurva ini menunjukkan karakteristik dari aliran atau debit. Kurva durasi debit dapat dapat dibentuk dari data debit harian, rata-rata 10 harian, rata-rata 15 harian dan rata-rata bulanan. Flow Duration Curve (FDC) pada daerah pengaliran sungai (DAS) lokasi rencana PLTM Aek Silang-2 dapat dilihat pada Gambar 7.

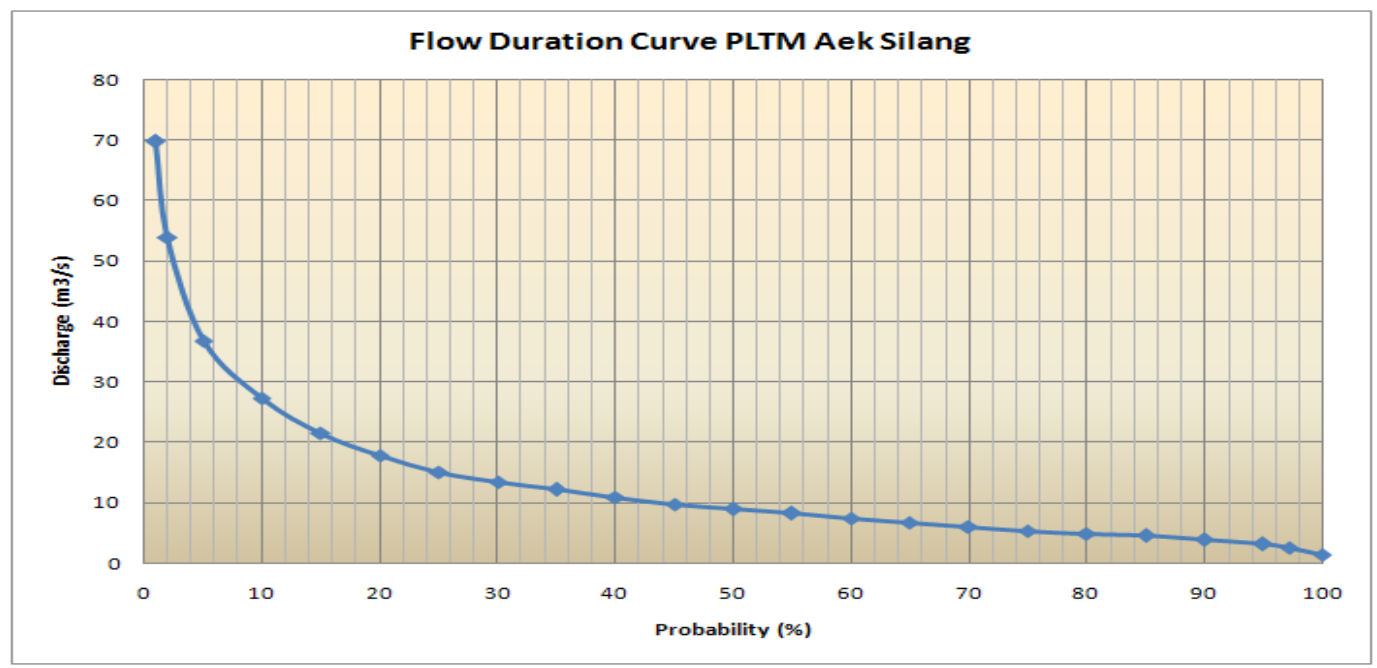

Gambar 7. Kurva Durasi Debit (FDC) DAS PLTM Aek Silang-2

\subsubsection{Debit Andalan dengan Hydrologic Engineering Center's Hydrologic Modeling System (HEC-HMS)}

Software HEC-HMS merupakan salah satu komponen dari HEC Next Generation Software Development Project. Sofware ini dikembangkan oleh Hydrologic Engineering Center (HEC) dari The US Army Corps of Engineers. Dalam software ini 
terdapat fasilitas kalibrasi maupun simulasi model distribusi, model menerus dan kemampuan membaca data GIS.

Di dalam HEC-HMS terdapat beberapa model yang terpisah dimana masingmasing model yang dipilih mempunyai input yang berbeda-beda. Beberapa model yang digunakan untuk menghitung volume runoff, direct runoff, baseflow dan channel flow ditunjukkan pada tabel berikut :

Tabel 6. Perhitungan dan model yang terdapat dalam HEC-HMS

\begin{tabular}{|l|l|}
\hline \multicolumn{1}{|c|}{ Perhitungan } & \multicolumn{1}{|c|}{ Model } \\
\hline Precipitation & User hyetograph \\
& User gage weighting \\
& Inverse distance gage weights \\
& Gridded precipitation \\
& Frequency storm \\
& Standard project storm \\
\hline Volume runoff & Initial and Constant rate \\
& SCS curve number (CN) \\
& Gridded SCS CN \\
& Green and Ampt \\
& Deficit and constant rate \\
& Soil moisture accounting (SMA) \\
& Gridded SMA \\
\hline Direct runoff & User-spesified unit hydrograph \\
(overland flow dan interflow) & Clark's UH \\
& Snyder's UH \\
& SCS UH \\
& Modclark \\
Kinematic wave
\end{tabular}

Penyelesaian dan perhitungan masing-masing model mempunyai komponen dan variabel tetap, parameter, kondisi batas dan kondisi awal. Output software ini yang digunakan nantinya adalah debit andalan DAS Aek Silang-2.

Sesuai dengan fasilitas yang terdapat dalam HEC-HMS dan pertimbangan parameter-parameter yang dibutuhkan untuk simulasi dan faktor ketersediaan data, maka model-model hidrologi yang dipilih dalam analisis studi ini adalah :

1. Hujan (precipitation)

Metode model hujan menggunakan User Gage Weights. Metode ini menggunakan data stasiun pengukur hujan yang mempengaruhi di suatu sistem Daerah Aliran Sungai (DAS) dengan rentan tahun tertentu.

2. Volume Aliran (volume runoff) 
Dalam program HEC-HMS terdapat satu model yang digunakan untuk pemodelan menerus (continuous model) dalam menentukan volume aliran yaitu soil moisture accounting loss model. Model ini mampu mensimulasikan perilaku suatu DAS, baik pada saat cuaca basah maupun kering. Penggunaan model Soil Moisture Accounting (SMA) yang terdapat dalam paket program HEC-HMS bertujuan untuk mengetahui ketersediaan air pada suatu DAS tertentu. Dalam studi ini digunakan model SMA untuk mengetahui besarnya debit andalan $45 \%$ untuk DAS Aek Silang-2, yang kemudian dibandingkan dengan perhitungan menggunakan Tank Model.

1. Aliran Langsung (direct runoff)

Model direct runoff yang digunakan dalam model HEC-HMS adalah Snyder's Unit Hydrograph model.

2. Model aliran dasar (baseflow)

Aliran dasar (baseflow) merupakan aliran air yang tertahan berdasarkan hujan sebelumnya yang tertampung sementara di dalam tanah. Model baseflow yang digunakan dalam HEC-HMS adalah Constant monthly.

Tahapan simulasi model dimaksudkan untuk mencari debit simulasi berdasarkan data hujan terukur tahun 1993-2009. Parameter DAS yang digunakan untuk simulasi model adalah parameter DAS hasil optimasi model HEC-HMS. Pada tahap ini hasil yang didapat berupa debit harian yang akan digunakan untuk menghitung debit andalan $45 \%$. Adapun hasil simulasi model HEC-HMS untuk tahun 1993-2009 menghasilkan debit puncak sebesar $138,8 \mathrm{~m}^{3} / \mathrm{dt}$.

Berdasarkan simulasi HEC-HMS besarnya debit andalan pada daerah pengaliran sungai (DAS) PLTM Aek Silang-2 dengan berbagai macam keandalan disajikan dalam Tabel 7 berikut.

Tabel 7. Hasil Perhitungan Debit Andakan dengan HEC- HMS

\begin{tabular}{|l|l|l|}
\hline $\begin{array}{l}\mathrm{P} \\
\%\end{array}$ & $\begin{array}{l}\text { Frequency } \\
(\text { day })\end{array}$ & $\begin{array}{l}\text { Discharge (Q) } \\
\mathrm{m}^{3} / \mathrm{dt}\end{array}$ \\
\hline \hline 1 & 4 & 55.90 \\
5 & 19 & 36.50 \\
10 & 37 & 28.00
\end{tabular}




\begin{tabular}{|l|l|l|}
15 & 55 & 22.70 \\
20 & 73 & 19.20 \\
25 & 92 & 16.80 \\
30 & 110 & 14.80 \\
35 & 128 & 12.80 \\
40 & 146 & 11.20 \\
45 & 165 & 9.80 \\
50 & 183 & 8.40 \\
55 & 201 & 7.20 \\
60 & 219 & 6.10 \\
65 & 238 & 5.10 \\
70 & 256 & 4.30 \\
75 & 274 & 3.40 \\
80 & 292 & 2.70 \\
85 & 311 & 1.90 \\
90 & 329 & 1.30 \\
95 & 347 & 0.60 \\
100 & 365 & 0.10 \\
\hline$S u m b e r$ &
\end{tabular}

Sumber: Perhitungan

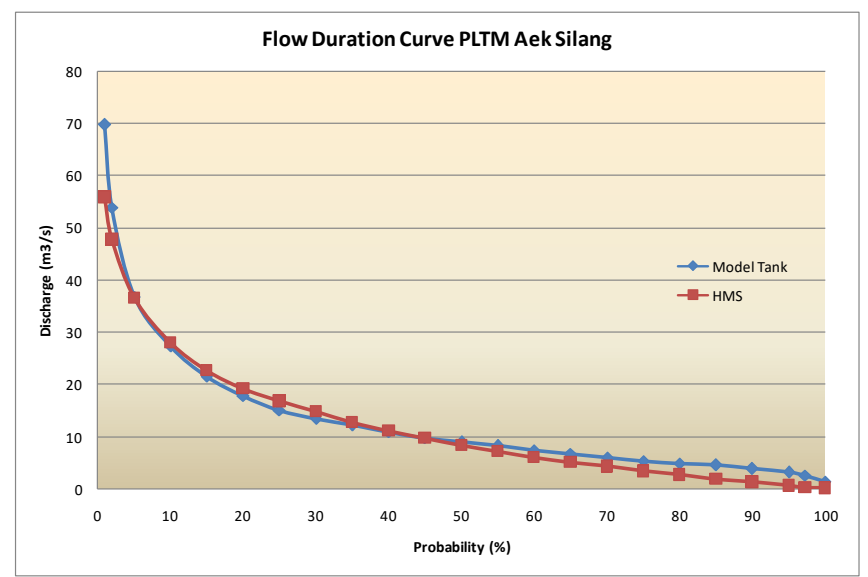

Gambar 8. Comparison Flow Duration Curve Tank Model dan HMS 
Untuk membandingkan hasil dari kedua metode antara metode Tank Model dan HEC-HMS maka dapat dilihat dari rangkuman Tabel 8 berikut :

Tabel 8. Debit andalan DAS Aek Silang-2 dengan simulasi HEC-HMS dan Tank

Model

\begin{tabular}{|c|c|c|c|}
\hline Probability & Frequency & $\begin{array}{l}\text { Discharge } \\
\text { (Q) } \\
\text { Tank } \\
\text { Model }\end{array}$ & $\begin{array}{l}\text { Discharge } \\
\text { (Q) } \\
\text { HMS }\end{array}$ \\
\hline$(\%)$ & (day) & $(\mathrm{m} 3 / \mathrm{dt})$ & $(\mathrm{m} 3 / \mathrm{dt})$ \\
\hline 1 & 4 & 69.798 & 55.90 \\
\hline 5 & 19 & 36.821 & 36.50 \\
\hline 10 & 37 & 27.270 & 28.00 \\
\hline 15 & 55 & 21.498 & 22.70 \\
\hline 20 & 73 & 17.775 & 19.20 \\
\hline 25 & 92 & 15.111 & 16.80 \\
\hline 30 & 110 & 13.423 & 14.80 \\
\hline 35 & 128 & 12.166 & 12.80 \\
\hline 40 & 146 & 10.879 & 11.20 \\
\hline 45 & 165 & 9.780 & 9.80 \\
\hline 50 & 183 & 8.959 & 8.40 \\
\hline 55 & 201 & 8.221 & 7.20 \\
\hline 60 & 219 & 7.499 & 6.10 \\
\hline 65 & 238 & 6.736 & 5.10 \\
\hline 70 & 256 & 6.047 & 4.30 \\
\hline 75 & 274 & 5.312 & 3.40 \\
\hline 80 & 292 & 4.920 & 2.70 \\
\hline 85 & 311 & 4.548 & 1.90 \\
\hline 90 & 329 & 3.830 & 1.30 \\
\hline 95 & 347 & 3.145 & 0.60 \\
\hline 100 & 365 & 1.350 & 0.10 \\
\hline
\end{tabular}

Sumber : Perhitungan 
Berdasarkan hasil diatas maka debit di DAS Aek Silang-2 untuk keandalan 45\% yang terjadi selama 165 hari adalah berkisar sebesar $9.8 \mathrm{~m}^{3} / \mathrm{dt}$.

\subsection{Debit Pemeliharaan (Maintenance Flow/Ecological Flow)}

Debit Pemeliharaan (maintenance flow) atau aliran Ekologi (ecological flow) adalah aliran air yang diperlukan untuk menjamin keberadaan habitat biota akuatik di sungai. Aliran ekologi dapat berupa berbagai kondisi aliran yang menggambarkan aliran rata-rata jangka panjang, variabilitas aliran termasuk aliran dengan debit rendah dan debit tinggi yang tidak teratur seperti saat kejadian banjir [EFG, 1999].

Berdasarkan analisa hidrologi yang telah dilakukan sebelumnya, diperoleh besaran debit rata-rata tahunan (Annual flow) 1993 - 2009 pada DAS PLTM Aek Silang-2 $=16.150 \mathrm{~m}^{3} /$ detik. Besarnya aliran ekologi menggunakan Metode Montana $=$ $10 \% \times 16.150 \mathrm{~m}^{3} /$ detik $=1.615 \mathrm{~m}^{3} /$ detik.

Sebagai metode pembanding, digunakan referensi dari Nippon Koei pada PLTA Asahan dimana aliran ekologi ditentukan sebesar $0.200 \mathrm{~s} / \mathrm{d} 0.500 \mathrm{~m}^{3} /$ detik/100 $\mathrm{Km}^{2}$. Besarnya aliran ekologi untuk DAS lokasi rencana PLTM Aek Silang - 2 dengan catchment area $276.90 \mathrm{~km}^{2}$ disajikan pada Table 9 berikut:.

Tabel 9. Aliran Ekologi Berdasarkan Referensi dari PLTA Asahan-3

\begin{tabular}{|c|c|c|c|c|}
\hline C.A & \multicolumn{4}{|c|}{ Aliran Ekologi $=0.2-0.5 \mathrm{~m} 3 /$ detik/100 Km2 } \\
\hline & \multicolumn{4}{|c|}{ Aliran Ekologi (QE), m3/detik } \\
\hline Km2 & 0.200 & 0.300 & 0.400 & 0.500 \\
\hline 276.9 & 0.554 & 0.831 & 1.108 & 1.385 \\
\hline
\end{tabular}

Berdasarkan tabel diatas diperoleh aliran ekologi untuk PLTM Aek Silang-2 sebesar $1.385 \mathrm{~m}^{3} / \operatorname{detik}\left(0.500 \mathrm{~m}^{3} /\right.$ detik $\left./ 100 \mathrm{~km}^{2}\right)$.

Berdasarkan dari teori Montana dan dikontrol dari referensi PLTA Asahan-3 yang didesain oleh Nippon Koei, maka besarnya aliran ekologi untuk PLTM Aek Silang-2 direncanakan sebesar $1.615 \mathrm{~m}^{3} /$ detik. 


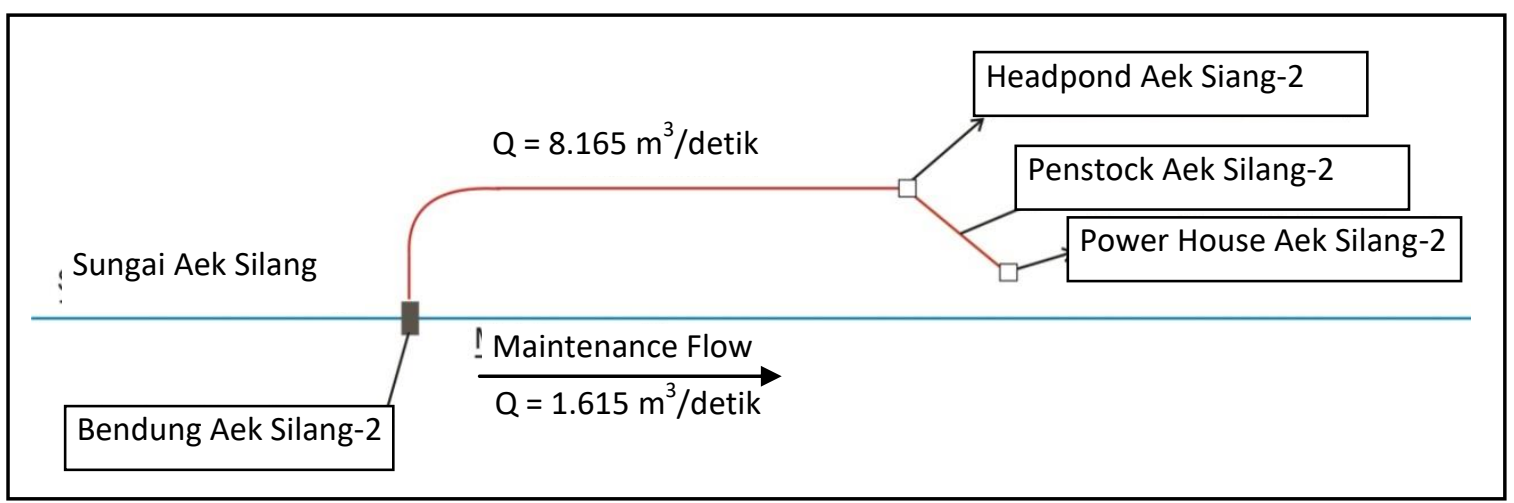

\section{Gambar 9. Skema Maintenance Flow PLTM Aek Silang-2}

\subsection{Potensi Pembangkit Listrik}

Debit andalan pada daerah pengaliran sungai (DAS) lokasi rencana PLTM Aek Silang-2 dengan berbagai macam probabilitas seperti ditunjukkan pada Grafik Flow Duration Curve (FDC) dan tinggi jatuh energi (head netto) sebesar 142.98 meter, maka potensi pembangkit listrik diperhitungkan dan disajikan dalam Tabel 10 sebagai berikut

Tabel 10. Potensi Pembangkit Listrik PLTM Aek Silang-2

\begin{tabular}{|c|c|c|c|c|c|}
\hline $\begin{array}{l}\text { Probability } \\
(\%)\end{array}$ & $\begin{array}{l}\text { Frequency } \\
\text { (days) }\end{array}$ & $\begin{array}{l}\text { Discharge } \\
\left(\mathrm{m}^{3} / \text { detik }\right)\end{array}$ & $\begin{array}{l}\text { Ecological } \\
\text { Flow } \\
\left(\mathrm{m}^{3} / \text { detik }\right)\end{array}$ & $\begin{array}{l}Q \text { install } \\
\left(\mathrm{m}^{3} / \text { detik }\right)\end{array}$ & $\begin{array}{l}\text { Install } \\
\text { Capacity } \\
\text { MW }\end{array}$ \\
\hline 1.00 & 3.65 & 69.798 & 1.615 & 68.183 & 83.506 \\
\hline 2.00 & 7.30 & 53.983 & 1.615 & 52.368 & 64.137 \\
\hline 5.00 & 18.25 & 36.821 & 1.615 & 35.206 & 43.118 \\
\hline 10.00 & 36.50 & 27.270 & 1.615 & 25.655 & 31.421 \\
\hline 15.00 & 54.75 & 21.498 & 1.615 & 19.883 & 24.351 \\
\hline 20.00 & 73.00 & 17.775 & 1.615 & 16.160 & 19.791 \\
\hline 25.00 & 91.25 & 15.111 & 1.615 & 13.496 & 16.529 \\
\hline 30.00 & 109.50 & 13.423 & 1.615 & 11.808 & 14.461 \\
\hline 35.00 & 127.75 & 12.166 & 1.615 & 10.551 & 12.923 \\
\hline 40.00 & 146.00 & 10.879 & 1.615 & 9.264 & 11.346 \\
\hline
\end{tabular}




\begin{tabular}{|c|c|c|c|c|c|}
\hline $\begin{array}{l}\text { Probability } \\
(\%)\end{array}$ & $\begin{array}{l}\text { Frequency } \\
\text { (days) }\end{array}$ & $\begin{array}{l}\text { Discharge } \\
\text { ( } \mathrm{m}^{3} / \text { detik) }\end{array}$ & $\begin{array}{l}\text { Ecological } \\
\text { Flow } \\
\text { (m³/detik) }\end{array}$ & $\begin{array}{l}Q \text { install } \\
\left(\mathrm{m}^{3} / \text { detik }\right)\end{array}$ & $\begin{array}{l}\text { Install } \\
\text { Capacity } \\
\text { MW }\end{array}$ \\
\hline 45.00 & 164.25 & 9.780 & 1.615 & 8.165 & 10.000 \\
\hline 50.00 & 182.50 & 8.959 & 1.615 & 7.344 & 8.995 \\
\hline 55.00 & 200.75 & 8.221 & 1.615 & 6.606 & 8.091 \\
\hline 60.00 & 219.00 & 7.499 & 1.615 & 5.884 & 7.206 \\
\hline 65.00 & 237.25 & 6.736 & 1.615 & 5.121 & 6.272 \\
\hline 70.00 & 255.50 & 6.047 & 1.615 & 4.432 & 5.429 \\
\hline 75.00 & 273.75 & 5.312 & 1.615 & 3.697 & 4.528 \\
\hline 80.00 & 292.00 & 4.920 & 1.615 & 3.305 & 4.048 \\
\hline 85.00 & 310.25 & 4.548 & 1.615 & 2.933 & 3.592 \\
\hline 90.00 & 328.50 & 3.830 & 1.615 & 2.215 & 2.712 \\
\hline 95.00 & 334.84 & 3.145 & 1.615 & 1.530 & 1.873 \\
\hline 97.26 & 346.75 & 2.518 & 1.615 & 0.903 & 1.106 \\
\hline 100.00 & 355.00 & 1.350 & 1.615 & 0.000 & 0.000 \\
\hline
\end{tabular}

Berdasarkan tabel diatas, dengan menggunakan debit rencana (Q install cap.) sebesar $8.165 \mathrm{~m}^{3} / \mathrm{dt}$ (164.25 hari, Q45\%) diperoleh kapasitas terpasang untuk PLTM Aek Silang-2 sebesar 10.000 ( 2 x 5.00 MW).

Sesuai hasil perhitungan optimasi dari berbagai macam debit dan nilai ekonomi (biaya energy yang harus dikeluarkan) untuk menghasilkan energi sebesar 1 $\mathrm{kWh}$, di dapatkan hasil yang paling optimum dengan menggunakan debit dengan probabilitas $45 \%$ dengan biaya energy sebesar Rp 557.54/kWh.

Perhitungan produksi $\mathrm{kWh}$ yang dihasilkan dalam setahun menghasilkan produksi listrik sebesar : $64.530 .792,94 \mathrm{kWh}$. Dengan debit andalan $45 \%$ sebesar 8,165 m³/det.

\section{KESIMPULAN}

\section{Kesimpulan}

Sesuai hasil perhitungan optimasi dari berbagai macam debit dan nilai ekonomi (biaya energy yang harus dikeluarkan) untuk menghasilkan energi sebesar 1 
$\mathrm{kWh}$, di dapatkan hasil yang paling optimum dengan menggunakan debit dengan probabilitas $45 \%$ dengan biaya energy sebesar Rp 557.54/kWh.

Perhitungan produksi kWh yang dihasilkan dapat dilihat pada Tabel 16. Dalam setahun produksi listrik yang akan dihasilkan diperkirakan sebesar : 64.530.792,94 $\mathrm{kWh}$. Dengan debit andalan $45 \%$ sebesar $8,165 \mathrm{~m}^{3} /$ det.

\section{DAFTAR PUSTAKA}

Engineering Manual for Irrigation \& Drainage., 1987, Small Scale Hydro Power Generation, Japan. Japan Institute of Irrigation and Drainage.

Gaorong, L. Dan Qiubo, M. 1996., Small Hydro Power In China. Experience \& Technology, Hangzhou. Hangzhou Regional Center (Asia-Pacific) for Small Hydro Power.

Gaorong, L. 1997., A Manual of China Small-Hydraulic Turbine-Generating Units, Hangzhou. Hangzhou Regional Center (Asia-Pacific) for Small Hydro Power.

Harvey, Adam. 1993., Micro-Hydro Design Manual, London. IT Publications.

J. Fritz, Jack. 1984., Small and Minihydro Power System Resource Assesment Project Fasibility, New York. McGraw-Hill,Inc.

Kementrian ESDM. 2010., Rencana Induk Pengembangan Energi Baru Terbarukan (Ripebat), 2010-2025. Jakarta. Kementrian ESDM

Kementrian ESDM. 2015. PERMEN ESDM No 19 Tahun 2015 Tentang Tentang Pembelian Tenaga Listrik Dari Pembangkit Listrik Tenaga Air (PLTA) Dengan Kapasitas Sampai Dengan 10 Megawatt (MW) Oleh PT Perusahaan Listrik Negara (PLN Persero), Jakarta. Kementrian ESDM.

Maryono, Dr. Ing. Ir. Agus. 2003., Hidrolika Terapan, Jakarta. PT. Pradnya Paramita Rahman, A. 2017., Pasokan Listrik Sumut Surplus, Tapi Pemadaman Masih Ada, (Http://Properti.Kompas.Com/Read/2017/09/07/141436621/Pasokan-Listrik-

Sumut-Surplus-Tapi-Pemadaman-Masih-Ada)

Soemarto, CD. 1987., Hidrologi Teknik. Surabaya, Usaha Nasional

Sosrodarsono, Ir. Suyono. 1987., Hidrologi Untuk Pengairan, Jakarta. PT. Pradnya Paramita. 
Jurnal Visi Eksakta (JVIEKS)

Vol.1, No.1, Juli 2020, pp. 99-122

Widodo, J. 2015., Pidato Lengkap Jokowi Di COP21 Paris, (Https://Nasional.Tempo.Co/Read/723604/Ini-Isi-Pidato-Lengkap-Jokowi-DiCop21-Paris). 